\title{
LONGSHORE CURRENT VERTICAL PROFILE ON A DISSIPATIVE BEACH
}

\author{
Gabriela Bueno Jung ${ }^{1}$ and Elírio Ernestino Toldo $\mathrm{Jr}^{2}$ \\ Recebido em 13 janeiro, 2011 / Aceito em 23 novembro, 2011 \\ Received on January 13, 2011 / Accepted on November 23, 2011
}

\begin{abstract}
Vertical profiles of velocity and longshore current direction were obtained in the main channel of a dissipative beach with longitudinal bar-through structure, using a SonTek ${ }^{\circledR}$ ADP (Acoustic Doppler Profiler), together with simultaneous measurements of wind and incident waves in the study area. Values recorded by the ADP show variations in velocity throughout the water column with minimum and maximum values of $0.10 \mathrm{~m} / \mathrm{s}$ and $0.83 \mathrm{~m} / \mathrm{s}$ respectively. The data show that flow is in the form of pulses with oscillations in direction along the water column controlled by current velocity, being greatest in the surface layers and becoming weaker with depth. The highest velocities of current propagation correspond to the largest angles of wave incidence which, during the period of record, reached values between $1.4^{\circ}$ and $10.9^{\circ}$.
\end{abstract}

Keywords: hydrodynamics, longshore currents, surf zone.

RESUMO. Perfis verticais de velocidade e direção da corrente longitudinal foram obtidos no canal principal de uma praia dissipativa com a presença de bancos e cavas Iongitudinais através da utilização de um ADP (Acoustic Doppler Profiler) da marca SonTek ${ }^{\circledR}$, concomitantemente às observações do vento e ondas incidentes na área de estudo. Valores registrados pelo ADP mostram variações de velocidade ao longo da coluna d'água, com valores mínimos de 0,10 m/s e máximos de 0,83 m/s. Os dados indicam que o fluxo ocorre na forma de pulsos, com oscilações da direção ao longo da coluna d'água controladas pela velocidade da corrente, mais intensa nas camadas superficiais, diminuindo de intensidade próximo ao fundo. As maiores velocidades de propagação das correntes ocorrem associadas aos maiores ângulos de incidência das ondas que, durante os registros de corrente, atingiram valores entre $1,4^{\circ}$ e $10,9^{\circ}$.

Palavras-chave: hidrodinâmica, correntes longitudinais, zona de surfe.

\footnotetext{
1 Universidade Federal do Rio de Janeiro, UFRJ, Laboratório de Tecnologia Submarina LTS/COPPE, Caixa Postal 68508, 21945-970 Rio de Janeiro, RJ, Brazil. Phone: +55 (21) 8034-2917 / 2562-7790 / 2562-7794 - E-mail: jung.oceano@gmail.com

2Universidade Federal do Rio Grande do Sul, UFRGS, Centro de Estudos de Geologia Costeira e Oceânica CECO, Instituto de Geociências, Avenida Bento Gonçalves, 9500, Prédio 43125, Porto Alegre, RS, Brazil. Phone: +55 (51) 3308-9855 / 3308-7302 - E-mail: toldo@ufrgs.br
} 


\section{INTRODUCTION}

The hydrodynamics in the surf zone are complex and mainly controlled by the incident waves which dissipate their energy by breaking, forming currents. The main flows extending throughout the whole of the surf zone are the undertow, rip currents, and longshore currents (Short, 1999). Longshore currents are flows of coastal water parallel to the line of the beach; they are generated by waves or wind and develop from the obliqueness of wave incidence and from longitudinal variation in the height of wave-break. They increase in intensity towards the open sea and attain their maximum in the middle of the surf zone, beyond which they decrease (Wright, 1985).

Longshore currents generated by winds are temporary and occur locally, their most notable effect being to disperse fine sediments (Drake, 1976 apud Lanfredi \& Framiñan, 1986).

Along the coast of the Brazilian State of Rio Grande do Sul (Fig. 1), the distribution of longshore current directions is highly regular towards both SW and NE in a pattern that is clearly bidirectional. Nicolodi et al. (2000) reported that in years 1996 and 1997 the main current direction was SW for 62.8 and $54.8 \%$ of the time respectively, whilst in 1998 and 1999 there was am inversion, with a NE current for 54 and $51.2 \%$ of the time. It has also been found that the bi-directionality has a seasonal component determined by climatic factors. From October to March, the main current direction is towards the SW, whilst between May and August it is to the NE.

Within the surf zone the vertical structure of water flow is strongly controlled by wave-break and by currents induced by waves. Unlike other shallow-water regions, turbulence is dominant throughout the whole of the water column. At depths less than $5 \mathrm{~m}$, the surface and bottom boundary layers are superimposed on the intermediate layer, producing turbulence and different types of movement not yet fully understood (Feddersen et al., 2007). Velocities within the water column are modified by the turbulence of incoming waves and by bed morphology, especially those velocities near the bottom.

Field studies of the behavior of longshore currents do not usually consider the vertical structure of flow, nor the effects of bed morphology. This study reports an analysis of hydrodynamic data collected in the surf zone at Tramandaí beach on the northern coast of the Rio Grande do Sul State, a wide sandy dissipative beach with longitudinal bar-through structure (Toldo Jr. et al., 1993). The data were collected in field campaigns with wave measurements taken in shallow water, together with velocity and direction of current developing in the main channel between the outer and inner bars.

\section{STUDY AREA}

The beach of Tramandaí, situated on the northern coast of Rio Grande do Sul, has facilities for mounting oceanographic equipment in the form of a fishing platform, at which instantaneous measurements of velocity and direction of longshore current were recorded. The platform is $365 \mathrm{~m}$ long, $8 \mathrm{~m}$ wide, and is T-shaped (Fig. 2).

This northern beach forms part of the long State coast-line extending in the NE-SW direction with slight curvature along its length of $615 \mathrm{~km}$ (Fig. 2). The whole area consists of unconsolidated quaternary deposits which are free of more recent sand deposits, since all material transported from the interior by its drainage system is retained in lagoons and other coastal environments such as the Lagoa dos Patos and the Lagoa Mirim. The Continental Platform is part of a wide and inactive margin, more than $150 \mathrm{~km}$ long, with maximum depth varying between 100 and $140 \mathrm{~m}$ and gentle slope of about $0.06^{\circ}$. The foreshore of the beach is wide and flat with an outer limit of depth $10 \mathrm{~m}$, where sand deposits predominate (Toldo Jr. et al., 2006). The beach at Tramandaí runs at an angle of about $110^{\circ}$.

The beach is subject to swells generated in the Southern Atlantic Ocean and sea produced by the strong local winds of spring and summer, blowing from the NE. Except when cold fronts arrive from the $S$ and $S E$, the sea surface is characterized by waves with medium to high energy with significant height $1.5 \mathrm{~m}$ and period between 7 and $9 \mathrm{~s}$. The astronomical tide is semi-diurnal with mean amplitude $0.25 \mathrm{~m}$, and the meteorological tide may reach $1.20 \mathrm{~m}$ (Almeida et al., 1997). The closure depth is estimated as $7.5 \mathrm{~m}$, calculated from two sets of wave data collected in years 1963 and 1996 on the State's northern coast (Almeida et al., 1999).

\section{METHODOLOGY}

Data on the velocity and direction of longshore current were collected using a SonTek ${ }^{\circledR}$ ADP (Acoustic Doppler Profiler). The equipment was configured to record values of current velocity and direction at depth intervals of $0.5 \mathrm{~m}$, with exception of the more superficial layer of the water column, considering the blanking cell of $0.45 \mathrm{~cm}$. Each profile of data collected lasted for two minutes with frequency $1.5 \mathrm{MHz}$, with equidistant cells over depth at increasing by steps of $0.25 \mathrm{~m}$.

The ADP equipment, fixed to a wooden support (Fig. 3), was launched into the sea surface with the aid of a tripod (Fig. 4), from the wall of the fishing platform that was exposed to incoming waves. A set of ropes, attached to the wooden support, were used 


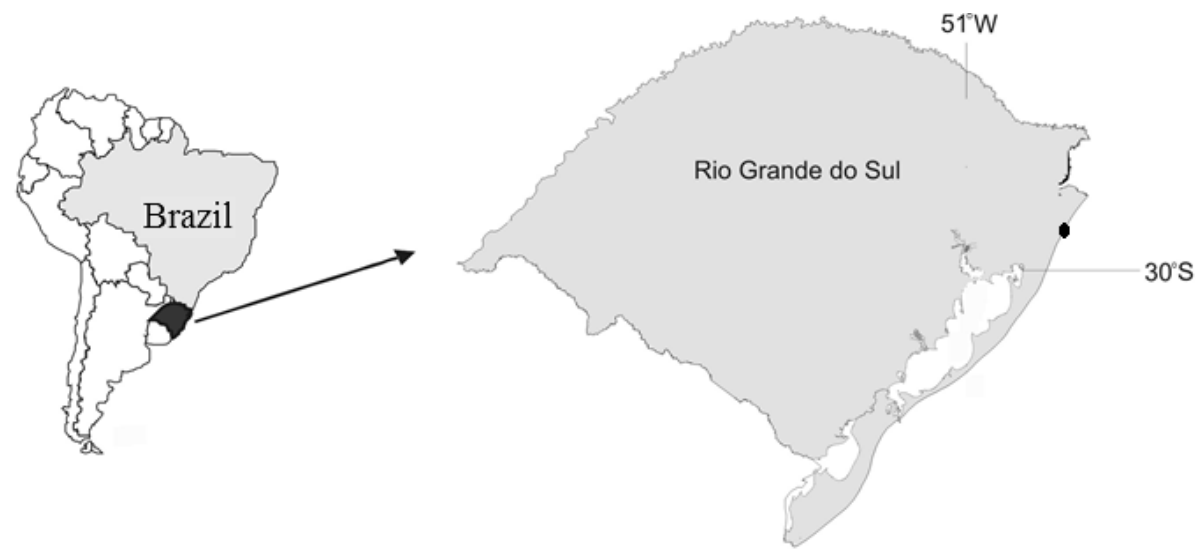

Figure 1 - Location of study area (black dot) on the southern coastal zone of Brazil.

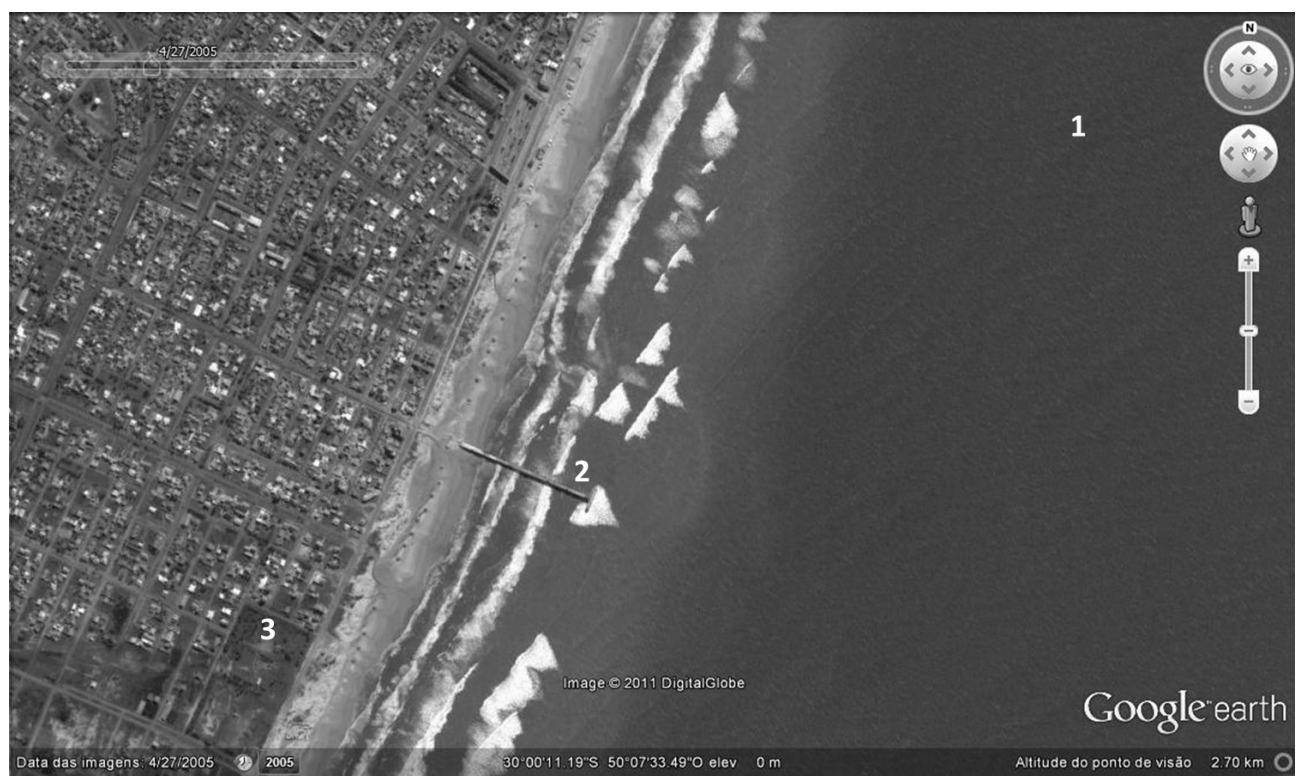

Figure 2 - Position of Tramandaí beach on the State's northern coast. The Google Earth ${ }^{\circledR}$ image shows the three points of data collection: the site of the wave recorder is shown (1), currents on the fishing platform (2), wind on the land-based meteorological station (3).

to stabilize the launching and to reduce the equipment movement once it started making the longshore currents registers.

Field procedures after launch included positioning the transducers towards the sea-bed and configuring the apparatus with the "Bottom Track" system, to give the sea-bed direction as reference. Errors of inclination and drift of the device are corrected automatically.

Data were always collected in the main channel of the surf zone, i.e., between the positions of the first and second bars identified visually from the line of wave-break (Fig. 2). This is the most appropriate region for collecting current data as it is free of the direct effects of turbulence that occur at the first line of wave-break.
During the course of the project there were three field campaigns to make simultaneous measurements of current and waves. Table 1 shows the number of profiles measured during each field campaign. The mean velocity and resultant direction were calculated for each profile recorded.

Table 1 - Number of profiles measured in each field campaign.

\begin{tabular}{|c|c|}
\hline Date & Number of profiles \\
\hline $04 / 30 / 2008$ & 04 \\
$10 / 01 / 2008$ & 04 \\
$10 / 21 / 2009-13 h$ & 06 \\
$10 / 21 / 2009-14 h$ & 04 \\
$10 / 21 / 2009-15 h$ & 06 \\
$10 / 21 / 2009-16 h$ & 05 \\
\hline
\end{tabular}




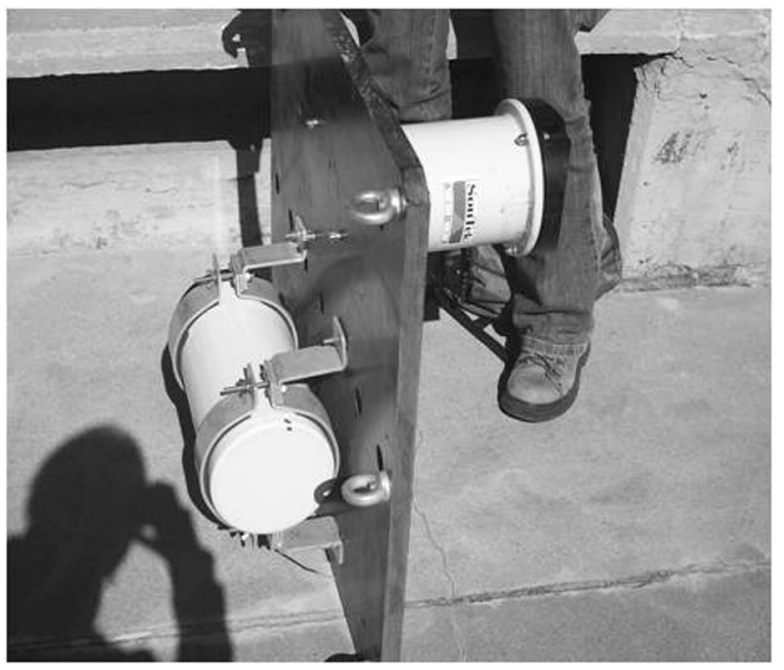

Figure 3 - Details of the ADP (SonTek ${ }^{\circledR}$ ) equipment and frame used for current measurement.

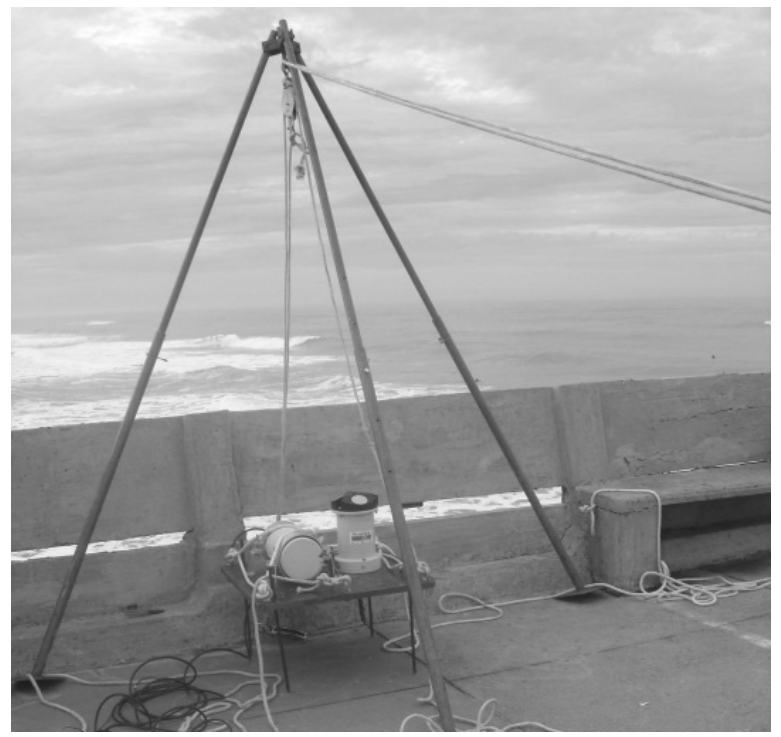

Figure 4 - Tripod used to launch the ADP into the surf zone from the fishing platform.

In the field campaigns of 2008 the significant wave height was estimated visually using an aluminium ruler, taking as reference the line between the horizon and the height of the observer's eye. Wave period was measured using the time taken for ten consecutive crests to pass through the platform pillars, whilst the angle of incidence was estimated visually using as reference the angle between the line of the beach and the first wave-break.

In 2009 the directional wave meter Waverider of Datawell was moored near the beach at the point with co-ordinates $29^{\circ} 59^{\prime} 58^{\prime \prime} \mathrm{S}, 50^{\circ} 06^{\prime} 09^{\prime \prime} \mathrm{W}$, at $17 \mathrm{~m}$ depth. Considering the depth of the Waverider's anchoring is in intermediate waters, and when waves propagate through shallow whaters they are afeccted by the sea floor, generating refraction, it's high and incidence angle change on the way to the break point. So, Wave's Linear Theory's equations were applied to calculate Hs and incidence angle in shallow waters, as proposed on Chapter 4 of Shore Protection Manual (USACE, 1984). Local wind data were obtained from Tramandaí Meteorological Station of UFRGS, throughout the whole period of the study.

\section{RESULTS AND DISCUSSION}

Wave, wind and longshore current measurements are shown in Table 2. Positive values of current velocity indicate movement towards the north-east, negative values movement towards the south-west. Incident waves in the field campaign of 04/30/2008 had period $13 \mathrm{~s}$, significant height $2.37 \mathrm{~m}$ and incidence angle $121^{\circ}$. During the campaign of $10 / 30 / 2008$, the period was about $9.25 \mathrm{~s}$, significant height $2.53 \mathrm{~m}$ and angle of incidence $106^{\circ}$. The waverider measurements of 10/21/2009 showed significant wave height varying between $1.05 \mathrm{~m}$ and $1.25 \mathrm{~m}$, the period between $6.9 \mathrm{~s}$ and $7.2 \mathrm{~s}$, and the angle between 100.1 and $112.8^{\circ}$.

The wind velocity was very similar in all field campaigns, between $5.3 \mathrm{~m} / \mathrm{s}$ and $5.9 \mathrm{~m} / \mathrm{s}$. In the campaigns of 2008 the prevailing wind direction was from the NNE and NE, and in the campaigns of 2009 from ENE to $E$.

The ADP records are illustrated in Figure 5, giving the mean velocities and direction throughout the water column between -0.5 and $-3.5 \mathrm{~m}$ for all profiles surveyed in each field campaign (Table 2). The dotted line in the profiles of current direction shows the inclination of the local coastline, SW-NE, roughly $110^{\circ}$.

Profiles, in all field campaigns, show higher velocities near the surface, and smaller velocities near bottom areas. Faster currents were registered in field campaign of 04/30/2008. This situation is associated with a high incidence angle of swell, in order of $11^{\circ}$. Data show that the current's response to waves is instantaneous, being influenced mostly by changes in wave's incidence angles that happened during day 10/21/2009. On Figure 6, wave's registers show a similar high and oscillating incidence angle. The dot line represents the coast line position.

During the day there's a changing in wave's propagation direction. At $13 \mathrm{~h}$ it showed a south propagation, while current velocity was $0.4 \mathrm{~m} / \mathrm{s}$. At $14 \mathrm{~h}$, as waves become more parallel to the beach, velocity's current is smaller, maintaining a low velocity of propagation at $15 \mathrm{~h}$, when wave's approach angle changes again. Even being the instant of higher waves, when there's a transition of quadrant; wave's tendency is to lose intensity. At 16h, with south waves, the longshore current assumes higher values. 
Table 2 - Meteo-oceanographic parameters and velocities of longshore currents recorded during the course of the project, where $\mathrm{T}=$ period $(\mathrm{s}), \mathrm{Hs}=$ significant height $(\mathrm{m})$, Dir = angle of incidence $\left(^{\circ}\right)$, Vel $=$ velocity $(\mathrm{m} / \mathrm{s})\left({ }^{*}\right.$ data collected by eye-level measurements).

\begin{tabular}{|c|c|c|c|c|c|c|c|c|}
\hline \multicolumn{2}{|c|}{ Profile } & \multicolumn{3}{c|}{ Wave } & \multicolumn{2}{c|}{ Wind } & \multicolumn{2}{c|}{ Longshore current } \\
\hline Date & Time & T & Hs & Dir & Vel & Dir & Bottom vel. & Surface vel. \\
\hline 04/30/08 & $11: 00 \mathrm{~h}$ & 13 & 2.37 & 121 & 5.6 & 42 & 0.55 & 0.83 \\
10/01/08* & $11: 30 \mathrm{~h}$ & 9.25 & 2.53 & 106 & 5.3 & 25 & -0.30 & -0.49 \\
$10 / 21 / 09$ & $13: 00 \mathrm{~h}$ & 7.2 & 1.05 & 109.6 & 5.3 & 68 & -0.10 & -0.40 \\
10/21/09 & $14: 00 \mathrm{~h}$ & 6.9 & 1.09 & 112.8 & 5.4 & 81 & -0.13 & -0.35 \\
10/21/09 & $15: 00 \mathrm{~h}$ & 6.9 & 1.25 & 100.4 & 5.9 & 97 & -0.12 & -0.34 \\
10/21/09 & $16: 00 \mathrm{~h}$ & 7.2 & 1.11 & 100.1 & 5.8 & 91 & -0.12 & -0.37 \\
\hline
\end{tabular}
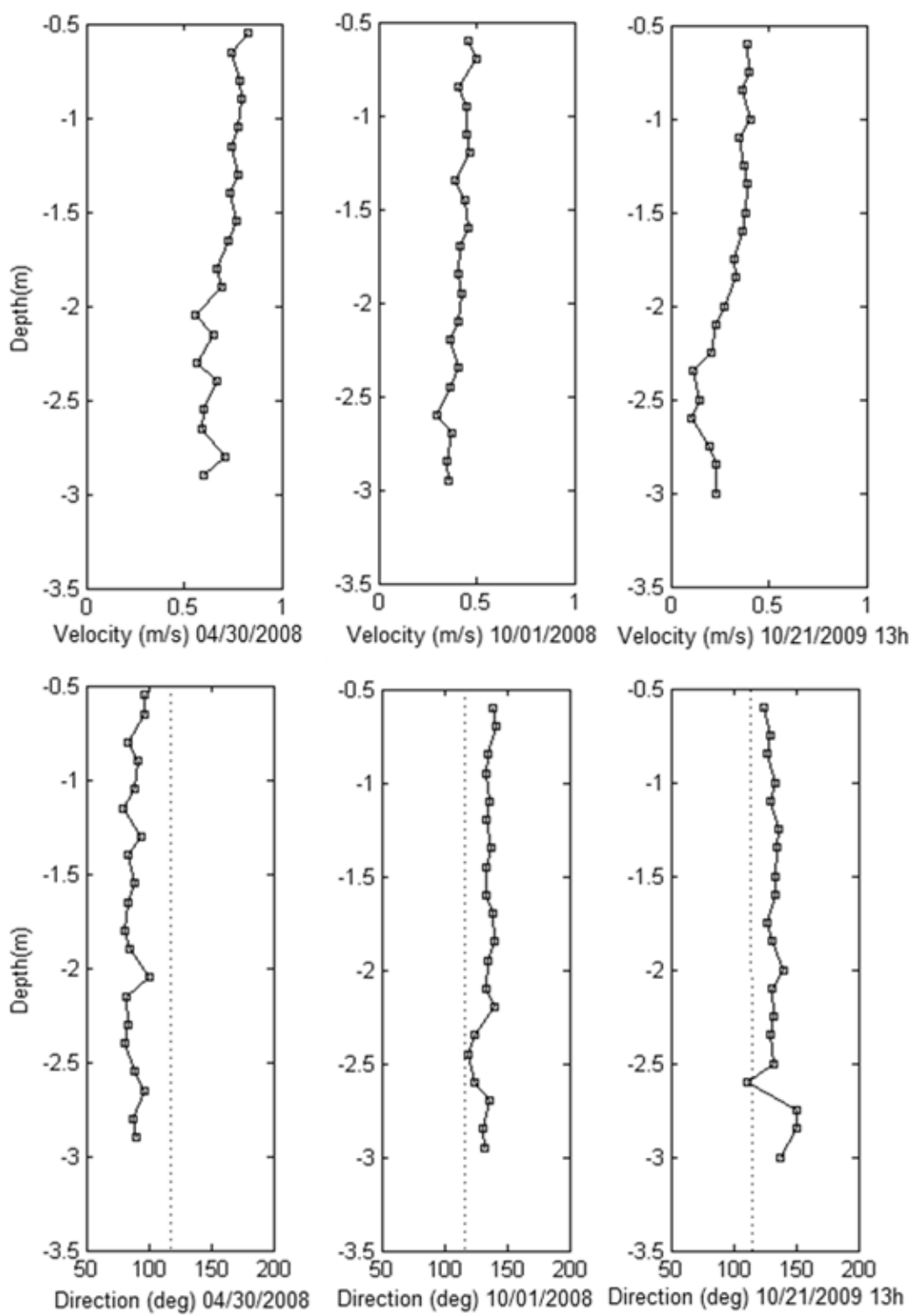

Figure $\mathbf{5}$ - Profiles of longshore current velocity and direction. 

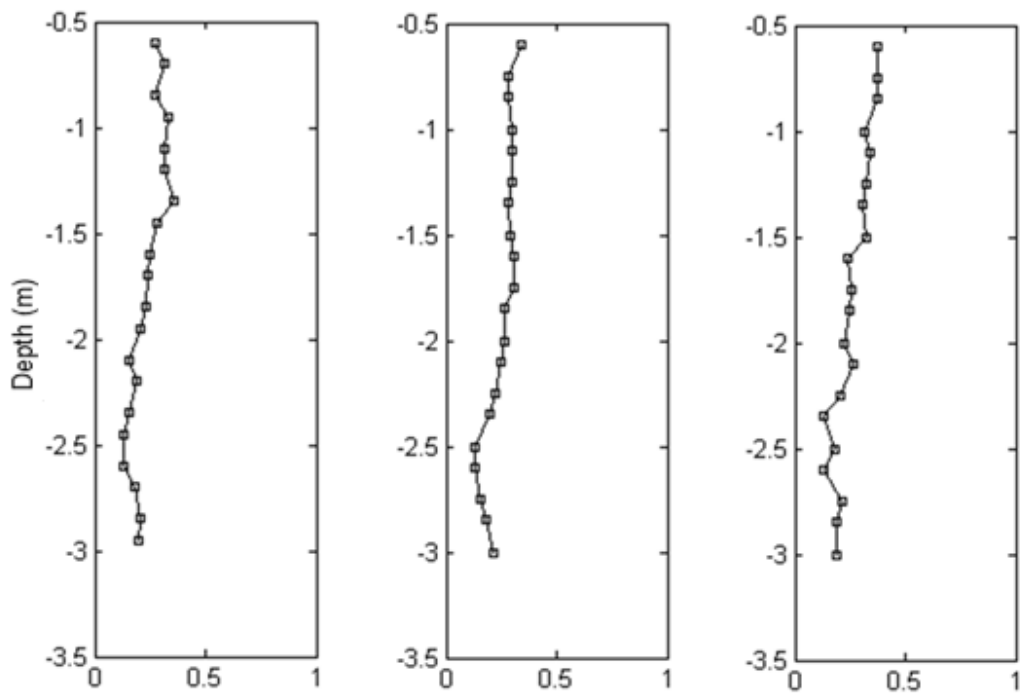

Velocity $(\mathrm{m} / \mathrm{s})$ 10/21/2009 $14 \mathrm{~h}$
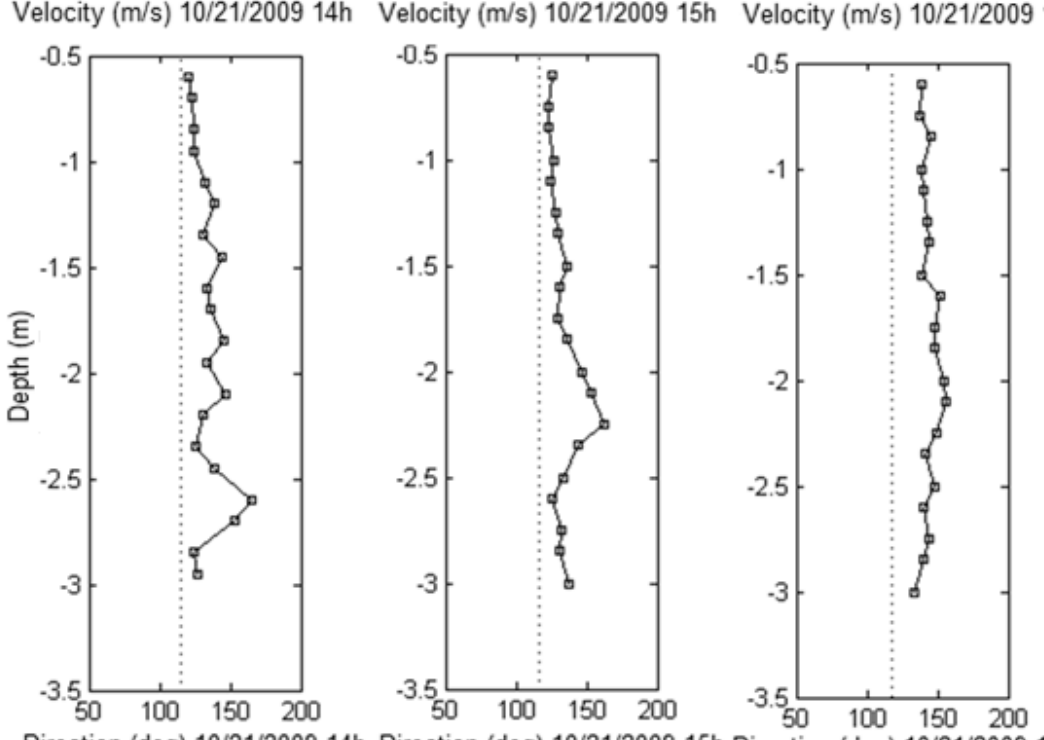

Direction (deg) 10/21/2009 14h Direction (deg) 10/21/2009 15h Direction (deg) 10/21/2009 16h

Figure 5 (continuation) - Profiles of longshore current velocity and direction.
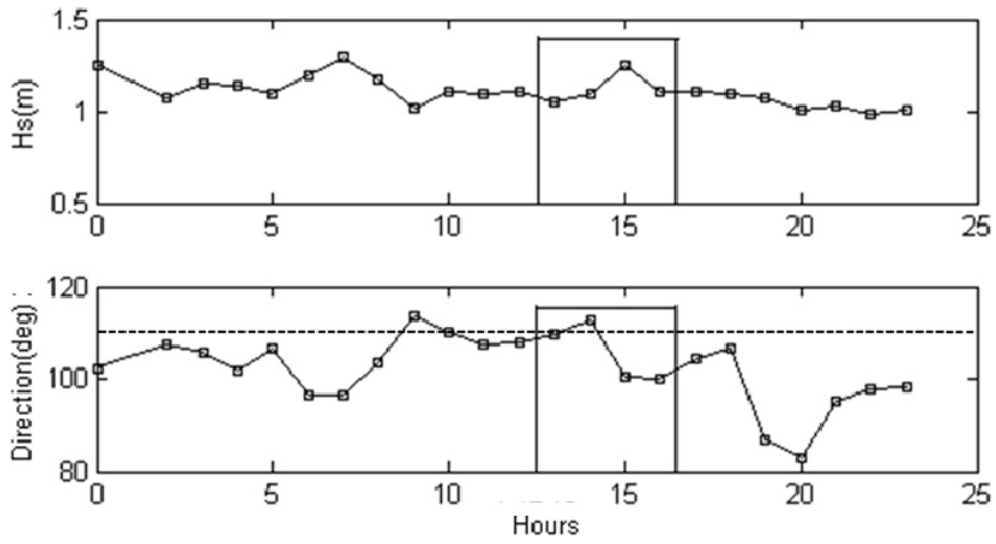

Figure 6 - Records from the directional waverider on 10/21/2009. 
Table 3 - Relation between wave height $(\mathrm{m})$, incidence angle (degrees), morphodynamic classification and values of longshore current velocity ( $\mathrm{m} / \mathrm{s}$ ).

\begin{tabular}{|c|c|c|c|c|c|c|}
\hline Reference & Beach & Classification & Hs & Incidence angle & Current & Sampling method \\
\hline Castelle \& Bonneton (2002) & Truc Vert (France) & Intermediate & 1 to 1.3 & Up to 10 & 0.05 to 1.2 & ADV \\
Castelle et al. (2006) & Aquitanian (France) & Intermediate & 2 & Up to 8 & 0.5 to 1 & ADV \\
Hubertz (1986) & Duck, CN (USA) & Reflective & 0.3 to 3 & 12 to 23 & 0.11 to 0.84 & Current Meter \\
Lanfredi \& Framiñan (1986) & Unión (Argentina) & Dissipative & 0.87 & - & 0.2 to 1 & Drifter \\
Toldo Jr. et al. (1993) & Imbé, RS & Dissipative & 1.19 to 1.93 & 3 to 10 & 0.07 to 0.87 & Dispersant \\
Feddersen \& Guza (2003) & Duck, CN (USA) & Reflective & 0.15 to 2.7 & -47 to 58 & $<1.7$ & Current Meter \\
Fontoura (2004) & Cassino, RS & Dissipative & 0.5 to 0.75 & 3 to 8 & 0.4 to 0.8 & Drifter \\
Calliari et al. (2005) & Cassino, RS & Dissipative & 0.6 to 2 & - & 0 to 0.5 & PUV \\
Lisniowski (2006) & Cassino, RS & Dissipative & 0.3 to 0.7 & 2 to 20 & 0.095 to 0.66 & Drifter \\
Jung et al. (2008a) & Cassino, RS & Dissipative & 0 to 0.95 & Up to 9 & 0 to 0.66 & Drifter \\
Jung et al. (2008b) & Cassino, RS & Dissipative & 0.4 to 1.4 & Up to 12 & 0 to 1.13 & Drifter \\
\hline
\end{tabular}

Between $13 \mathrm{~h}$ and $16 \mathrm{~h}$ winds remained light and from the same quarter, ENE-E (Table 3).

The profiles show small fluctuations, both in velocity and direction, throughout the water column (Fig. 7). The direction of the current near the surface is in agreement with the dispersion of energy flux from the incident waves, after wave-break. This was found in all field campaigns, even where wind direction differed from the direction of waves.

The greatest changes in direction were at depths greater than $2 \mathrm{~m}$, although no changes or inversions in the direction of propagation were found: only variations within the same quadrant. In situations where the longshore current had velocity of propagation lower then $0.5 \mathrm{~m} / \mathrm{s}$, as in the profile of 10/21/2009 at $13 \mathrm{~h}$, the direction of current becomes more closely parallel to the beach line. The same happened in the profiles of 10/01/2008 and 10/21/2009 at 15h. These profiles show more uniformity in the velocity through the water column, not only in velocity but also in direction, where profiles show smaller changes among water layers.

The reduction in velocity of the current below $2 \mathrm{~m}$ can be explained by the contact of the flow with the external and internal bars near the data collection point. Greenwood \& Sherman (1985) report that regions of wave-break show increased gradient of momentum flux, with higher current propagation velocities. In the hollows, which are deeper, the gradient is smaller, causing reduction in velocity of the current.

When the behavior of vertical profiles of current intensity is analyzed, records are found where velocities are different at the same depths, showing that flow behavior is not uniform (Fig. 7).
Differences along the length of the profiles, and oscillations in the values measured, show that current moves in pulses. From the graphs in Figure 5, showing mean values of velocity and direction of longshore current, it is not possible to detect whether the oscillations are present. However the raw profiles recorded at each sampling hour 13h, 14h, 15h and 16h (Fig. 7), reveal the oscillations in velocity along the whole of the water column.

There is little variation amongst the velocity values recorded at each hour (Fig. 7). Profiles are measured every two minutes and show oscillations at all sampling depths, indicating that the propagation of flow is not continuous, but occurs as pulses. This could happened due to sampling acquisition frequency.

The greater current intensities in layers nearer the surface can be explained by the transfer of momentum from wind to sea surface, and by the turbulence caused by breaking waves. Windshear at the water surface causes a transfer of energy which is transmitted among water layers, but which is dissipated at greater depths in the water column. It is expected that in the presence of swells there would be a greater transfer of momentum from wind to ocean as the sea surface becomes rougher, increasing the contact surface and, in consequence, the transfer of energy (Whitford \& Thornton, 1993). Coastal currents developed by wind-shear are less intense than currents developed by waves.

The surface velocities recorded were $0.83 \mathrm{~m} / \mathrm{s}, 0.45 \mathrm{~m} / \mathrm{s}$, $0.39 \mathrm{~m} / \mathrm{s}, 0.27 \mathrm{~m} / \mathrm{s}, 0.34 \mathrm{~m} / \mathrm{s}$ and $0.37 \mathrm{~m} / \mathrm{s}$. These values are consistent in magnitude with those found in earlier work, where velocities of between 0.07 and $0.87 \mathrm{~m} / \mathrm{s}$ were reported for the beach at Imbé (Toldo Jr. et al., 1993), and between 0.2 and $0.6 \mathrm{~m} / \mathrm{s}$ for the beach at Mar Grosso (Alvarez et al., 1981). 

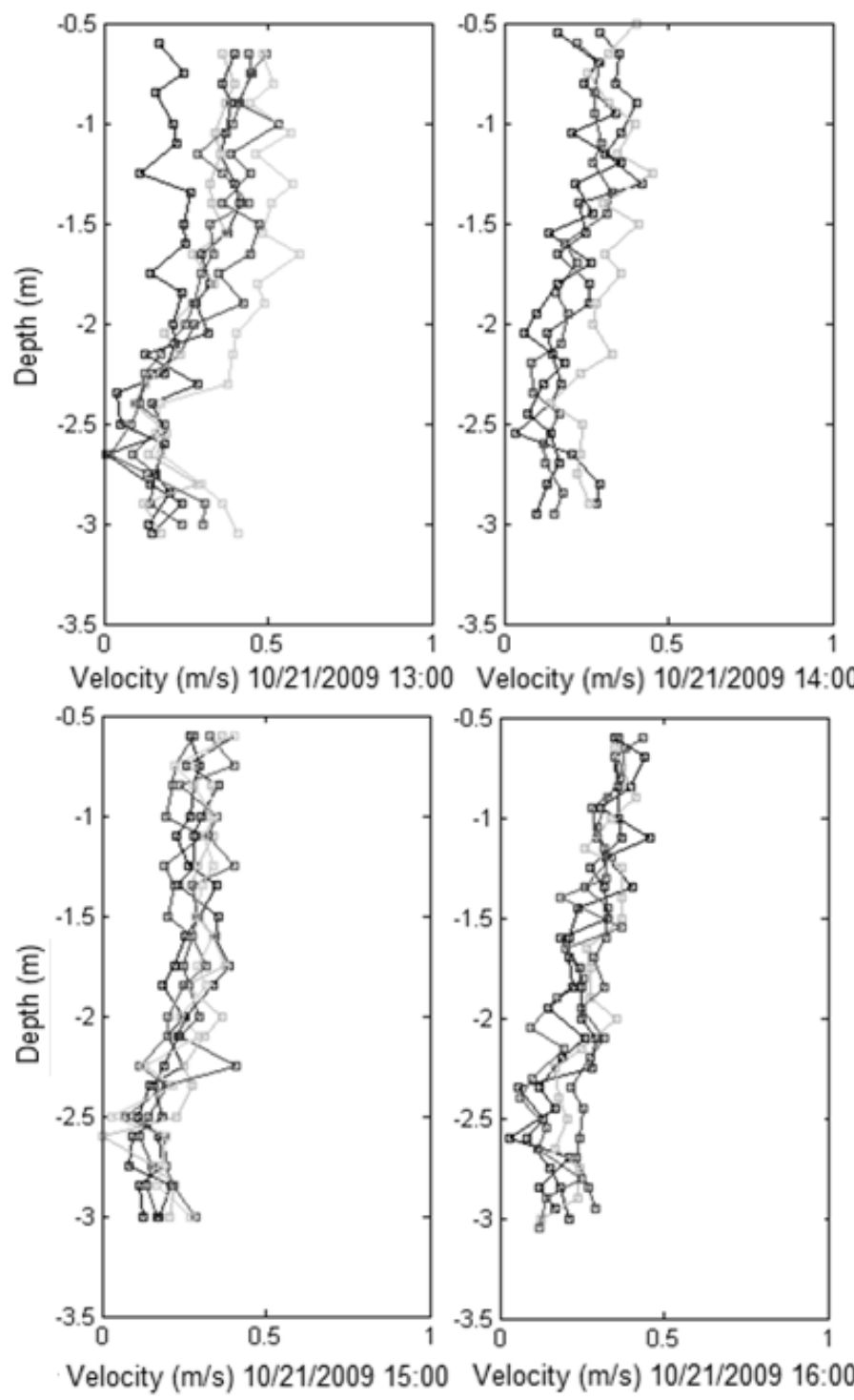

Figure 7 - Raw velocity profiles from the 10/21/2009 field campaign.

The minimum velocities measured, between 0.1 and $0.13 \mathrm{~m} / \mathrm{s}$, are smaller than those found in the literature, perhaps because of the way in which samples were collected. It is possible that the use of devices such as the ADP gives more accurate and more sensitive measurements so that even very low minimum flows, around $0.05 \mathrm{~m} / \mathrm{s}$, the detection limit of the equipment.

In general, sandy beaches with multiple banks on different coasts give values of longshore surface current intensities that are very similar. This is seen from the summary of earlier work in Table 2, giving beach classification, significant height and incidence angle of waves, and variation in values of current intensities.
The relation between significant height and surface current velocity can be seen in Figure 8, and between wave's direction and surface current velocity in Figure 9 . Wave height during the campaigns of $04 / 30 / 2008$ and 10/01/2008 were very similar, with a small difference of $0.16 \mathrm{~m}$, but with significant differences in angle of incidence, of $11^{\circ}$ and $4^{\circ}$, respectively, in relation to the line of beach (Table 3).

The smallest values for current were in the campaign of 10 / 21/2009, when the smallest wave heights and smallest angles of incidence were also found. It is therefore noted that the greatest velocities of surface current are associated with the greatest wave heights and the greatest angles of wave incidence. Jung 
et al. (2008b) observed a similar result at Cassino Beach on the southern RS coast, where calculation of a Pearson correlation coefficient between the variables resulted in a positive linear relationship.

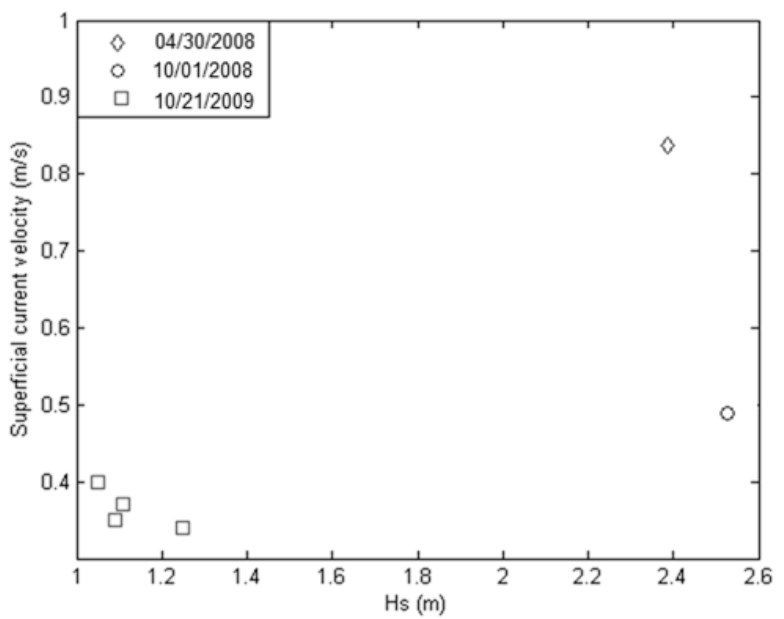

Figure 8 - Relation between Hs and surface current velocity.

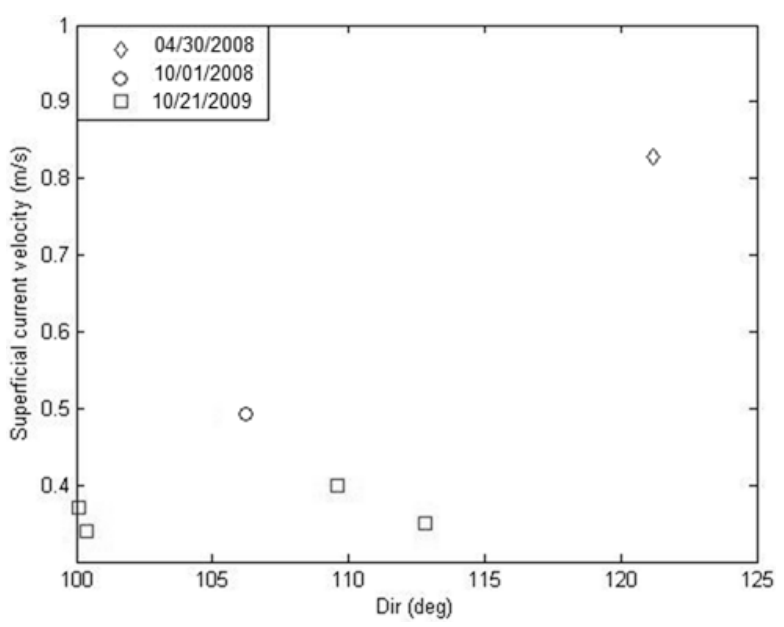

Figure 9 - Relation between Hs and surface current velocity.

Fontoura (2004), in a study also at Cassino Beach, observed that more intense currents were associated with higher waves and greater angles of incidence, and reported that currents to the north-east were faster than those to the south-west. This behaviour is to be expected along the coast of RS, since waves with this characteristic are associated with cold fronts coming from the south.

Observations on sandy beaches with multiple bars in the United States, and with a single bar in Holland, show that waves are the principal driver of currents, whilst the wind effect is 20 to $25 \%$ of the effect of waves in the surf zone (Ruessink et al., 2001).
Comparison of data recorded by the ADP and incident waves agree with the conjecture of Longuet-Higgins (1970), who considered that wave height and angle of incidence were the most significant variables for flow propagation. Estimated values of current velocity are given in Table 4, obtained by calculation based on the Longuet-Higgins (1970) formula, adapted in the Shore Protection Manual (USACE, 1984). Values used in the equation were: $H_{b}$ and $\alpha_{b}=$ measured in field campaigns, $g=$ 9.81 and $m=1 / 30$, proposed by Toldo Jr. et al. (1993) to Tramandaí beach.

$$
V=20.7 m\left(g . H_{b}\right)^{1 / 2} \sin 2 \alpha_{b}
$$

Equation 1 - Velocity of longshore current (Shore Protection Manual, USACE, 1984, adapted from Longuet-Higgins, 1970).

where

$$
\begin{array}{lll}
m & =\text { beach face slope; } \\
g & =\text { acceleration due to gravity; } \\
H_{b} & =\text { height at which waves break; } \\
\alpha_{b} & =\text { angle of incidence of waves. }
\end{array}
$$

Table 4 - Estimated velocities of longshore current obtained using the LonguetHiggins (1970) equation, compared with velocities observed in the field ( ${ }^{*}$ data collected by eye's high measurements).

\begin{tabular}{|c|c|}
\hline $\begin{array}{c}\text { Measured velocity } \\
(\mathrm{m} / \mathrm{s})\end{array}$ & $\begin{array}{c}\text { Estimated velocity } \\
(\mathrm{m} / \mathrm{s})\end{array}$ \\
\hline $0.83^{*}$ & 0.62 \\
$0.49^{*}$ & 0.23 \\
0.40 & 0.01 \\
0.50 & 0.11 \\
0.40 & 0.39 \\
0.37 & 0.38 \\
\hline
\end{tabular}

The calculated values are smaller when the incidence angle of the waves are closely parallel to the beach, and higher when waves show a high incidence angle. Estimated and measured values differ, however, Pearson's linear correlation indicates a significant positive correlation of 0.714 . The correlation was calculated between the surface and the estimated velocities, since the equation gives the surface velocity of the longshore current. The significant correlation is consistent with earlier results reported by Toldo Jr. et al. (1993) and Lanfredi \& Framiñan (1986), who compared observed data with estimates given by the Longuet-Higgins equation, also with good results.

The scatter plot in Figure 10 shows points concentrated near to the line, indicating high correlation between measured and calculated values. 


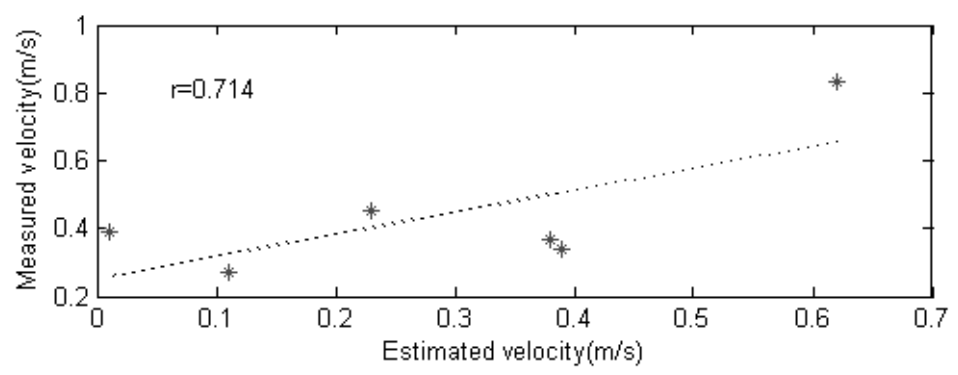

Figure 10 - Scatter plot showing dispersion of measured and estimated values of longshore current.
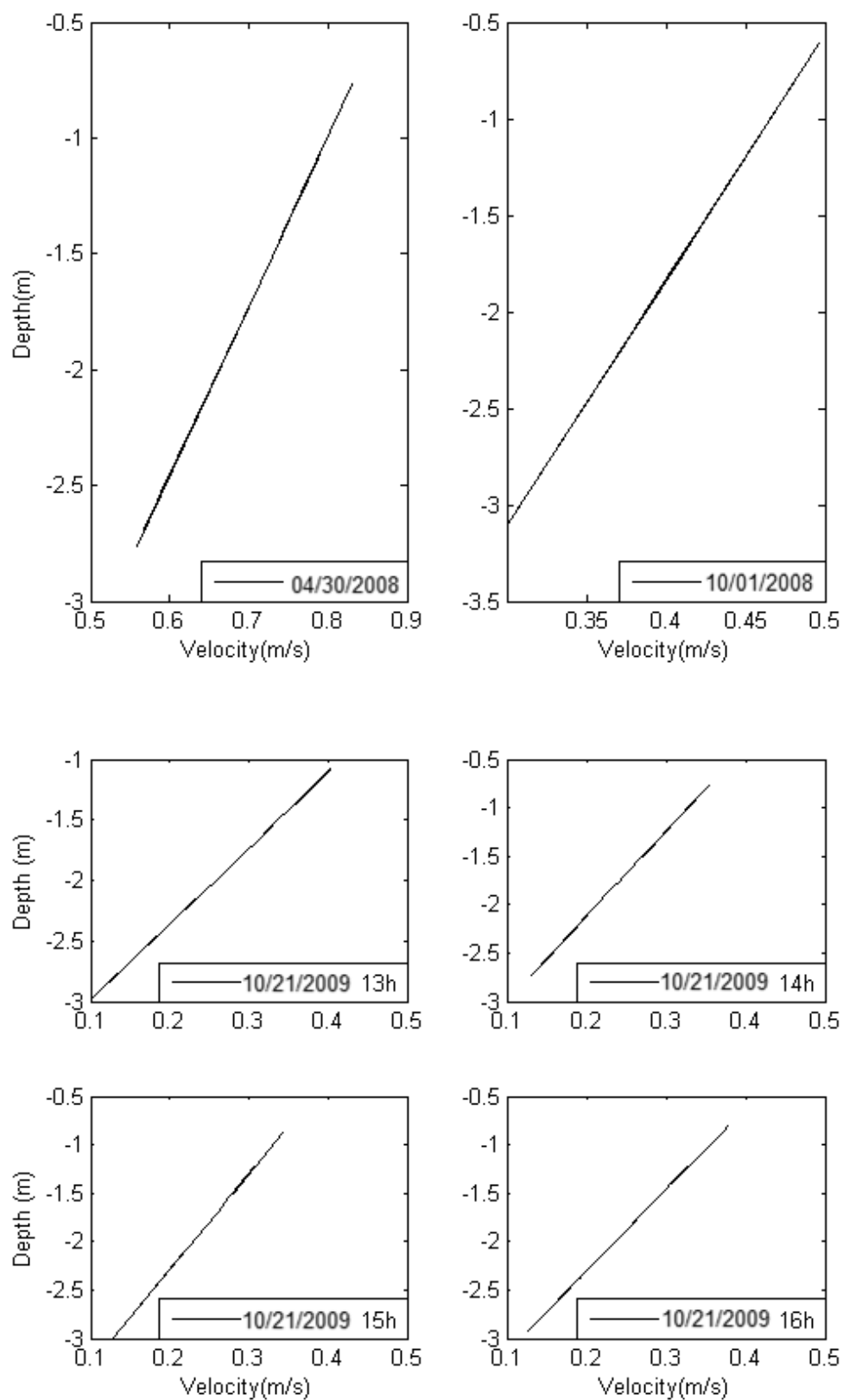

Figure 11 - Trend lines of velocity of longshore current. 
To visualize the vertical trend in velocity of the longshore current, trend lines were fitted to the observed data. Intense flows show the same direction for the surface current, whilst less intense flows force the fit towards the direction of propagation, with the current moving parallel to the beach line (Fig. 11).

In all velocity profiles analyzed, the reduction in current intensity with increasing depth is notable. Turbulence caused by waves breaking on the external bar and the transfer of momentum from wind to sea surface can be associated with more intense records obtained nearer the surface.

This is consistent with results of Wang et al. (2002) who used averages over time down through the water column to show that the trend showed lower velocities nearer to the sea-bed.

Feddersen et al. (2007) stated that magnitudes down the water column can only be clearly differentiated when the longshore current is quite strong, and that the surface is the principal source of turbulence, thus explaining the similar values obtained throughout the water column and why peaks of maximum velocity occur nearer to the surface than at depth.

\section{CONCLUSIONS}

Along the water column, the longshore current was found to be strongest near the surface and in the intermediate water layer, with weakest velocities near the sea-bed. This is the result of the influence of turbulence from waves breaking on the external bar and from the momentum transferred from wind to the upper and intermediate water layers. The ADP records didn't measure the superficial layer of the water column, which is expected to present the highest values of longshore currents. The lowest velocities, near to the bed, are associated with the morphology of the main channel, which being at greater depth shows lower hydrodynamics.

Flow was found to be non-uniform, and with an instantaneous response to variations in the incident wave field. The least variability amongst profiles, and the greatest variations in the direction of current propagation, was observed in regions near to the bottom, where mean currents are smaller.

Current direction is controlled by flux intensity. The upper and intermediate portions of the water column, which are more directly affected by incoming waves, show uniformity of direction, consistent with the direction of wave propagation. But from the intermediate portion down to the bottom of the main channel, where the greatest reductions in current velocity occur, the flow direction tends to become parallel to the coastline, principally when the current velocity is close to zero.

\section{REFERENCES}

ALMEIDA LESB, ROSAURO NML \& TOLDO Jr EE. 1997. Análise Preliminar das Marés na Barra do Rio Tramandaí, RS. In: Anais do XII Simpósio Brasileiro de Recursos Hídricos, Vitória, ES. ABRH, 1: 560-566.

ALMEIDA LESB, ROSAURO NML, TOLDO Jr EE \& GRUBER NLS. 1999. Avaliação da profundidade de fechamento para o litoral norte do Rio Grande do Sul. In: Anais do XIII Simpósio Brasileiro de Recursos Hídricos, Belo Horizonte, MG. 1 CD-ROM.

ALVAREZ JA, GRÉ JC \& TOLDO Jr EE. 1981. Estudos da praia a nordeste do molhe de Rio Grande - Rio Grande do Sul. Pesquisas, Porto Alegre, 14: $131-147$.

CALLIARI LJ, HOLAND T, DIAS MS, VINZON S, THORTON EB \& STANTON TP. 2005. Experimento Cassino 2005: uma síntese dos levantamentos efetuados na ante-praia e zona de arrebentação. In: Anais do X Congresso da Associação Brasileira de Estudos do Quaternário, Vitória, ES, ABEQUA, CD-ROM.

CASTELLE B \& BONNETON P. 2002. Wave-induced currents over the Aquitanian Coast on sand bars. In: 8th International Symposium on Oceanography of the Bay of Biscay, CD-ROM.

CASTELLE B, BONNETON P, SÉNÉCHAL N, DUPUIS H, BUTEL R \& MICHEL D. 2006. Dynamics of wave-induced currents over an alongshore non-uniform multiple-barred sandy beach on the Aquitanian Coast, France. Continental Shelf Research, 26: 113-131.

FEDDERSEN F \& GUZA RT. 2003. Observations of nearshore circulation: alongshore uniformity. Journal of Geophysical Research, 108(C1): 3006, DOI: 10.1029/2001JC001293.

FEDDERSEN F, TROWBRIDGE JH \& WILLIAMS III AJ. 2007. Vertical structure of dissipation in nearshore. Journal of Physical Oceanography, 37: 1764-1777.

FONTOURA JAS. 2004. Hidrodinâmica costeira e quantificação do transporte longitudinal de sedimentos não coesivos na zona de surfe das praias adjacentes aos Molhes da Barra de Rio Grande, RS, Brasil (Aplicação às praias do Cassino, Mar Grosso e adjacências dos Molhes Leste e Oeste da embocadura do estuário da Lagoa dos Patos). Tese de doutorado, UFRGS. $281 \mathrm{p}$.

GREENWOOD B \& SHERMAN DJ. 1985. Longshore currents profiles and lateral mixing across the surf zone of a barred nearshore. Coastal Engineering, 10: 149-168.

HUBERTZ JM. 1986. Observations of local wind effects on longshore currents. Coastal Engineering, 10: 275-288.

JUNG GB, PEREIRA PS \& CALLIARI LJ. 2008a. Comportamento das correntes longitudinais na praia do Cassino, RS: análise durante 0 experimento Cassino (2005). In: Anais do III Congresso Brasileiro de Oceanografia, CD-ROM. 
JUNG GB, PEREIRA PS \& CALLIARI LJ. 2008b. Comportamento das correntes longitudinais na praia do Cassino, RS: análises de observações visuais (2007). In: Anais do III Congresso Brasileiro de Oceanografia, CD-ROM.

LANFREDI NW \& FRAMINNAN MB. 1986. Field Study and Prediction of Longshore Currents, Argentine Coast. Journal of Coastal Research, 2(4): 409-417.

LISNIOWSKI AM. 2006. Variação granulométrica nos sedimentos em suspensão transportados longitudinalmente na zona de surfe na praia do Cassino (RS). Trabalho de graduação do curso de Oceanologia, FURG. $99 \mathrm{p}$.

LONGUET-HIGGINS MS. 1970. Longshore currents generated by obliquely incident sea waves. Journal of Geophysical Research, 75: 6778-6789.

NICOLODI JL, TOLDO Jr EE \& GRUBER NLS. 2000. Análise da direcionalidade das correntes litorâneas no litoral norte do Rio Grande do Sul. In: Anais da XIV Semana Nacional de Oceanografia, p. 461-463.

RUESSINK BG, MILES JR, FEDDERSEN F, GUZA RT \& ELGAR S. 2001. Modeling the alongshore current on barred beaches. Journal of Geophysical Research, 106(C10): 22451-22463.

SHORT AD. 1999. Handbook of Beach and Shoreface Morphody- namics. Coastal Studies Unit, School of Geosciences University of Sidney, Australia. $379 p$.

TOLDO Jr EE, DILLENBURG SR, ALMEIDA LESB, TABAJARA LL, MARTINS RR \& CUNHA LOBP. 1993. Parâmetros morfodinâmicos da Praia de Imbé, RS. Pesquisas, 20(1): 27-32.

TOLDO Jr EE, NICOLODI JL, ALMEIDA LESB \& CORRÊA ICS. 2006. Coastal Dunes and Shoreface Width as a Function of Longshore Transport. Journal of Coastal Research, Itajaí, SC, SI39: 390-394.

USACE. U.S. Army Corps of Engineers. 1984. Shore Protection Manual. $4^{\text {th }}$ edition, U.S. Government Printing Office, Washington, DC. 652 pp.

WANG P, EBERSOLE BA, SMITH ER \& JOHNSON BD. 2002. Temporal and spatial variations of surf-zone currents and suspended sediment concentration. Coastal Engineering, 46: 175-211.

WHITFORD DJ \& THORNTON EB. 1993. Comparison of wind and wave forcing of longshore currents. Continental Shelf Research, 13: 1205-1218.

WRIGHT LD. 1985. Elementary notes concerning the physical energy regime of coastal zone. Department of Geological Oceanography. School of Marine Science, Virginia Institute of Marine Science of the College of William and Mary. 154 p.

\section{NOTES ABOUT THE AUTHORS}

Gabriela Bueno Jung. Graduated in Oceanography at Fundação Universidade Federal do Rio Grande - FURG, with Masters degree in Geosciences at Universidade Federal do Rio Grande do Sul - UFRGS. Currently working on a Ph.D. thesis at COPPE/UFRJ about ocean renewable energy with emphasis in tidal stream and ocean currents.

Elírio Ernestino Toldo Jr. Graduated in Geology and Ph.D. in Geosciences at Universidade Federal do Rio Grande do Sul - UFRGS. Associated Professor III at Mineralogy and Petrology Department - DEMIPE-IG-UFRGS, responsible for the classes of Sedimentology I, Coastal and Marine Geology for the Geology graduation course, and Coastal Processes at Geosciences Post-graduation Program. Has experience in Geologic Oceanography, with research emphasis in coastal processes of lacustrine and marine beaches, related to sediment dynamics, morfodynamics, erosion, and hydrodynamics. 